\title{
Механізми державно-громадського управління соціальною відповідальністю суб'єктів системи оздоровчо-рекреаційної рухової активності
}

\author{
Галина Путятіна
}

Харківська державна академія фрізичної культури, Харків, Україна

Анотація. Сучасне громадянське суспільство має бути активним, впливовим і розвиненим, оскільки відіграє одну з ключових ролей у розробці і реалізації ефективної державної політики, в тому числі у сфері фрізичної культури і спорту. Реальний стан ффункціонування та розвитку сфери фрізичної культури і спорту характеризується проблемним полем, а саме, недосконалою визнана система взаємовідносин між державою та іншими суб'єктами сфери, що перешкоджає популяризації фізичної культури і спорту. Дієві механізми управління системою оздоровчо-рекреаційної рухової активності населення дозволять на законодавчому рівні усунути причини виникнення проблем неврегульованості механізму здійснення контролю за кваліфрікацією кадрів у фітнес-індустрії, відносин меценатства та інвестицій у сорері фізичної культури і спорту, недостатньої кількості інформаційно-соціальних кампаній, спрямованих на популяризацію здорового способу життя, а також мотиваційних презентацій масового спорту. Мета. Здійснити теоретичне обґрунтування механізмів державно-громадського управління соціальною відповідальністю суб'єктів системи оздоровчо-рекреаційної рухової активності. Методи. Аналіз наукової літератури та документальних джерел, інформаційних ресурсів мережі Інтернет, передового зарубіжного та вітчизняного досвіду; логічний аналіз; системний аналіз; організаційний аналіз; структурнофункціональний аналіз; теоретичне прогнозування та організаційне моделювання. Результати. Аналіз сучасного стану механізмів взаємодії держави і інститутів громадянського суспільства в Україні свідчить про те, що ці явища ще не набули системного характеру. Незважаючи на певні напрацювання з питань управління на громадських засадах, значні зусилля з боку суб'єктів системи оздоровчо-рекреаційної рухової активності, державногромадське управління в Україні недостатньо інституційно сформоване, його функціональна здатність і реальний вплив залишаються ще низькими. В ході дослідження встановлено, що на формування соціальної відповідальності суб'єктів системи оздоровчо-рекреаційної рухової активності населення в Україні вливають такі чинники: структура економіки; міжнародна практика; недостатньо ефективна система соціального захисту; регуляторний тягар; відсутність інституційної підтримки; наявні порушення норм трудового законодавства Ключові слова: влада, самоврядування, фітнес, рекреація, партнерство.

\section{Halyna Putiatina}

\section{MECHANISMS OF STATE AND PUBLIC MANAGING SOCIAL RESPONSIBILITY OF THE SUBJECTS OF THE SYSTEM OF HEALTH RELATED AND RECREATIONAL MOTOR ACTIVITY}

Abstract. Modern civil society must be active, influential, and developed, as it plays one of the key roles in the development and implementation of effective state policy, including in the field of physical culture and sports. The real state of functioning and development of the sphere of physical culture and sports is characterized by a problem field, namely, the imperfect system of relations between the state and other subjects of the sphere, which hinders the promotion of physical culture and sports. Effective mechanisms for managing the system of health related and recreational motor activity of the population will eliminate at the legislative level the causes of unresolved mechanism of control over the qualification of personnel in the fitness industry, the relationship of philanthropy and investment in physical culture and sports, insufficient information and social campaigns aimed at promotion of a healthy lifestyle, as well as motivational presentations of mass-scale sports. Objective. Carry out a theoretical substantiation of the mechanisms of state and public managing social responsibility of the subjects of the system

Putiatina H. Mechanisms of state and public managing social responsibility of the subjects of the system of health related and recreational motor activity. Theory and Methods of Physical education and sports. 2020; 4: 90-95

DOI: 10.32652/tmfvs.2020.4.90-95
Путятіна Г. Механізми державногромадського управління соціальною відповідальністю суб'єктів системи оздоровчо-рекреаційної рухової активності. Теорія і методика фрізичного виховання і спорту. 2020; 4: 90-95 DOI: 10.32652/tmfvs.2020.4.90-95
Вступ. Закон України «Про фрізичну культуру і спорт» декларує основні засади державної політики у сфрері фрізичної культури і спорту, зокрема:

- визнання фрізичної культури і спорту як пріоритетного напряму гуманітарної політики держави;

- визнання фрізичної культури як важливого чинника всебічного розвитку особистості та фрормування здорового способу життя;

- забезпечення підтримки громадських об'єднань фрізкультурноспортивної спрямованості;

- забезпечення різноманітності, високої якості та доступності фрізкультурно-спортивних послуг для громадян;

- забезпечення умов для підтримання напрямів фрізичної культури і спорту.

В Україні система оздоровчо-рекреаційної рухової активності населення як пріоритетний напрям фрізичної культури і спорту та соціоприродна система є затребуваною галуззю життєдіяльності, що викликає необхідність формування відповідного апарату управління в цілісній системі взаємообумовлених суспільних відносин, а також являє відповідну політико-економічну державну структуру $[11,15,16]$. Осмислення специфріки системи оздоровчо-рекреаційної рухової активності населення, фрактично феномену людського світу видається необхідною передумовою подолання антропологічної та екологічної кризи сучасного суспільства.

Україна здійснює поступовий перехід до сталого економічного розвитку, її інтеграція до європейського і світового співтовариства вимагає запровадження сучасної практики взаємодії держави та громадських інституцій, яка посилила б взаємну відповідальність усіх учасників суспільного життя, створила умови для подальшого сталого розвитку суспільства $[13,16,17]$. 
of health related and recreational physical activity. Methods. Analysis of scientific literature and documentary sources, information resources of the Internet, advanced foreign and domestic experience; logical analysis; system analysis; organizational analysis; structural and functional analysis; theoretical forecasting and organizational modeling. Results. Analysis of the current state of mechanisms of interaction between the state and civil society institutions in Ukraine shows that these phenomena have not yet become systemic. Despite some developments in public administration issues, significant efforts by the subjects of the system of health related and recreational physical activity, public administration in Ukraine is insufficiently institutionalized, its functional capacity and real impact remain low. The study found that the formation of social responsibility of the subjects of the system of health related and recreational physical activity of the population in Ukraine is influenced by the following factors: the structure of the economy; international practice; insufficiently effective social protection system; regulatory burden; lack of institutional support; violations of labor legislation.

Keywords: power, self-government, fitness, recreation, partnership.

Враховуючи підвищення ролі громадянського суспільства в різних сферах діяльності органів державної влади та органів місцевого самоврядування, зокрема впровадження реформ у сорері фрізичної культури і спорту [8, 9], а також з метою налагодження ефективного діалогу та партнерських відносин органів державної влади, органів місцевого самоврядування з організаціями громадянського суспільства, передусім 3 питань забезпечення прав і свобод людини і громадянина, затверджено Національну стратегію сприяння розвитку громадянського суспільства в Україні на 2016-2020 рр., що зумовлено необхідністю створення державою сприятливих умов для розвитку різноманітних форм демократії участі, налагодження ефективної взаємодії громадськості з органами державної влади та органами місцевого самоврядування.

Активне, впливове і розвинене громадянське суспільство відіграє одну 3 ключових ролей у впровадженні нагальних суспільних змін і належного врядування, в управлінні державними справами і вирішенні питань місцевого значення, розробці і реалізації ефрективної державної політики у різних сфрерах, утвердженні відповідальної перед людиною правової держави, вирішенні політичних, соціально-економічних та гуманітарних проблем. Реалізація Національної стратегії у розвитку ссрери фізичної культури і спорту на рівні територіальних громад відбувається досить повільно, що підтверджено охарактеризованим проблемним полем сфрери фізичної культури і спорту у затвердженій Стратегії розвитку фі- зичної культури і спорту на період до 2028 р. [12], в якій одним із пріоритетних напрямів $€$ «Фізично активна нація», оскільки, експертами недосконалою визнана система взаємовідносин між державою та іншими суб'єктами сфрери, що перешкоджає популяризації фрізичної культури і спорту.

У статтях 3, 10 Міжнародної хартії фізичного виховання, фізичної активності та спорту зазначається, що лише узгоджені дії та співпраця між усіма зацікавленими сторонами на всіх рівнях $є$ необхідною умовою для захисту морально-етичних цінностей та потенційної користі фрізичного виховання, фізичної активності та спорту. Також Хартією передбачено необхідність участі представників влади, громадськості, фрізкультурно-спортивних організацій, засобів масової інфоормації, працівників освіти, дослідників, спортивних фуункціонерів, волонтерів, спортсменів, їхніх родин, суддів, глядачів у впровадженні принципів Хартії для інтересів людства. Означені зацікавлені сторони мають фрормувати стратегічне бачення та визначати альтернативні стратегії і пріоритети фуункціонування та розвитку фізичного виховання, фрізичної активності і спорту. Хартією декларуються такі принципи ефективного управління:

- використання прозорих демократичних процедур під час проведення виборів та прийняття рішень, регулярне проведення консультацій зі стейхолдерами; наявність чітко ссрормульованих положень про фрінансові перерозподіли, чітке використання принципів підзвітності та транспарентності;
- забезпечення дотримання міжнародних конвенцій з питань праці та основних прав людини;

- запровадження заходів з протидії корупції під час організації та проведення масштабних спортивних заходів;

- здійснення ревізій та нагляду за використанням ресурсів суспільства;

- діяльність спортивних організацій на умовах автономії з дотриманням міжнародних стандартів державного управління. При цьому взаємодія державних та громадських інституцій має базуватися на мінімізації виникнення розбіжностей, за рахунок чіткого визначення специфічних функцій, законних прав та меж відповідальності [19].

Проблеми організації системи оздоровчо-рекреаційної рухової активності різних груп населення $€$ предметом вивчення певного кола дослідників, які на основі аналітичного підходу розкрили б особливості змісту і структури системи оздоровчорекреаційної рухової активності [2-5, 10].

Таким чином, дієві механізми управління системою оздоровчорекреаційної рухової активності дозволяють усунути причини виникнення проблем, які характеризуються неврегульованістю на законодавчому рівні механізму здійснення контролю за кваліфікацією кадрів у фітнесіндустрії, відносин меценатства та інвестицій у сфрері фрізичної культури і спорту, недостатньою кількістю інсормаційно-соціальних кампаній, спрямованих на популяризацію здорового способу життя, мотиваційних презентацій масового спорту.

Дослідження виконано відповідно до плану наукової роботи ХДАФК на 2020-2025 рр. згідно з темою кафедри гімнастики, танцювальних видів спорту та хореограсрії «Теоретикометодологічні засади розвитку системоутворюючих компонентів фозичної культури (спорт, фрітнес і рекреація)» (номер держреєстрації 0120U101215).

Мета дослідження - здійснити теоретичне обґрунтування механізмів державно-громадського управління соціальною відповідальністю суб'єктів 


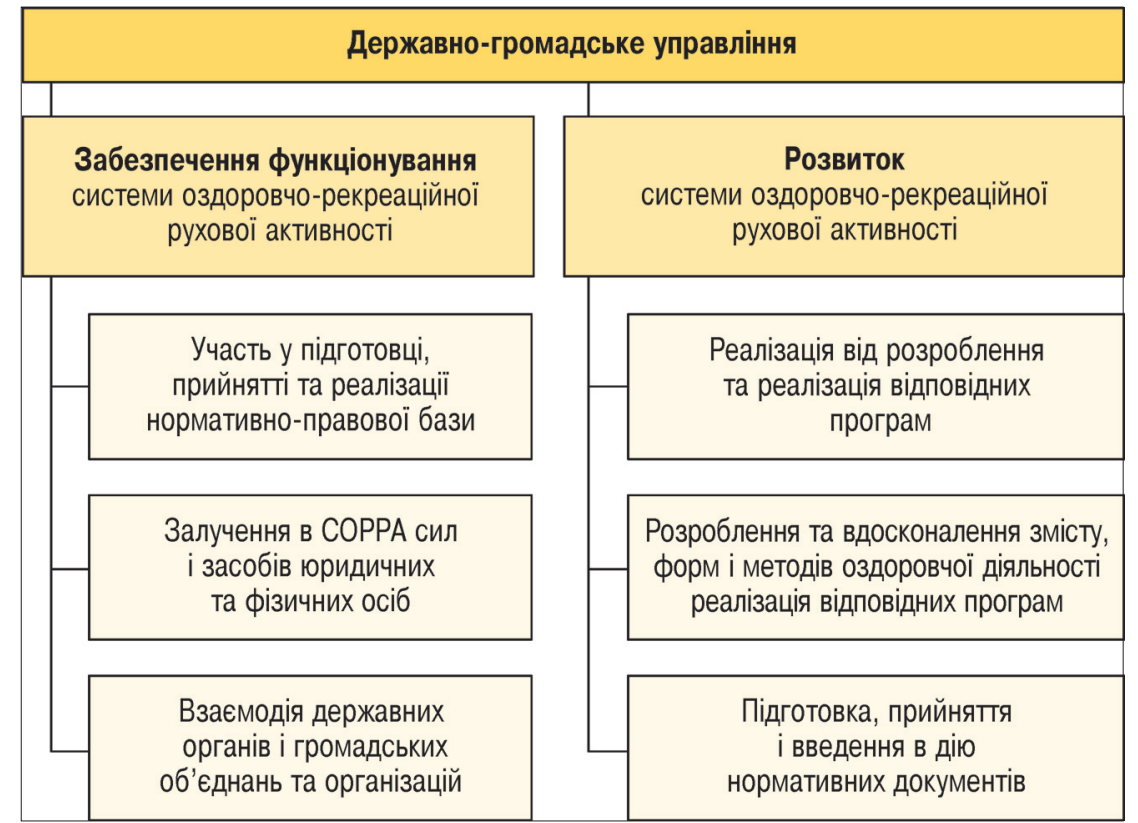

Рисунок 1 - Напрями державно-громадського управління системою оздоровчорекреаційної рухової активності

системи оздоровчо-рекреаційної рухової активності.

Методи дослідження: аналіз наукової літератури та документальних джерел, інформмаційних ресурсів мережі Інтернет, передового зарубіжного та вітчизняного досвіду; логічнийаналіз; системнийаналіз;організаційний аналіз; структурно-фрункціональний аналіз; теоретичне прогнозування та організаційне моделювання.

Результати дослідження та їх обговорення. Аналіз останніх досліджень свідчить, що вивченню проблеми становлення та розвитку державногромадської моделі управління системою оздоровчо-рекреаційної рухової активності приділяється все більше уваги як у сорері наукового пізнання, так і в практичних питаннях її реалізації $[1,6,7,14,18]$.

Вивчення основних законодавчих документів з питань державного управління, в тому числі системи оздоровчо-рекреаційної рухової активності, виявило, що беззаперечною ознакою політики України є суттєва зміна ролі держави в регулюванні суспільних відносин: вона набуває ознак соціально спрямованого керування, держава стає гарантом і захисником прав кожного громадянина, головними її функціями стають регулюючі та захисні, державна політика базується ційної рухової активності - діяльність його суб'єктів за двома напрямами (рис. 1).

Реалізація заходів із забезпечення функціонування системи оздоровчо-рекреаційної рухової активності сприятиме гармонізації, гуманізації та громадсько-правовому закріпленню різноманітних організаційних та організаційно-правових форм взаємовідносин усіх учасників. Щодо розвитку системи оздоровчорекреаційної рухової активності, то представлені заходи орієнтовані на її модернізацію та стимулювання діяльності організацій фрітнес-індустрії.

Проте аналіз сучасного стану механізмів взаємодії держави й інститутів громадянського суспільства в Україні свідчить про те, що ці явища ще не набули системного характеру.

Незважаючи на певні напрацювання 3 питань управління на громадських засадах, значні зусилля 3 боку суб'єктів системи оздоровчорекреаційної рухової активності, державно-громадське управління в Україні недостатньо інституційно ссрормоване, його функціональна здатність і реальний вплив залишаються ще низькими. Попри численні приклади впровадження його елементів на всіх управлінських рівнях, воно не набуло системності та залишається фррагментарним, маловпливовим.

Аналіз управлінських рішень окремих суб'єктів системи свідчить, що органи громадського самоврядування в системі оздоровчо-рекреаційної рухової активності працюють нерегулярно. Така ситуація, на нашу думку, пов'язана, перш за все, з недостатнім розвитком нормативно-правого механізму взаємодії інститутів громадянського суспільства та держави.

Згідно 3 міжнародним досвідом запровадження сталого розвитку, найбільших успіхів на цьому шляху досягли ті країни, які застосували інструменти та механізми, що сприяли дотриманню певних обмежень, подоланню значних перешкод, запровадженню нових стандартів, нормативів тощо. Тобто запровадження основних принципів досягнення балансу інтересів суб'єктів системи оздоровчорекреаційної рухової активності у пи- 


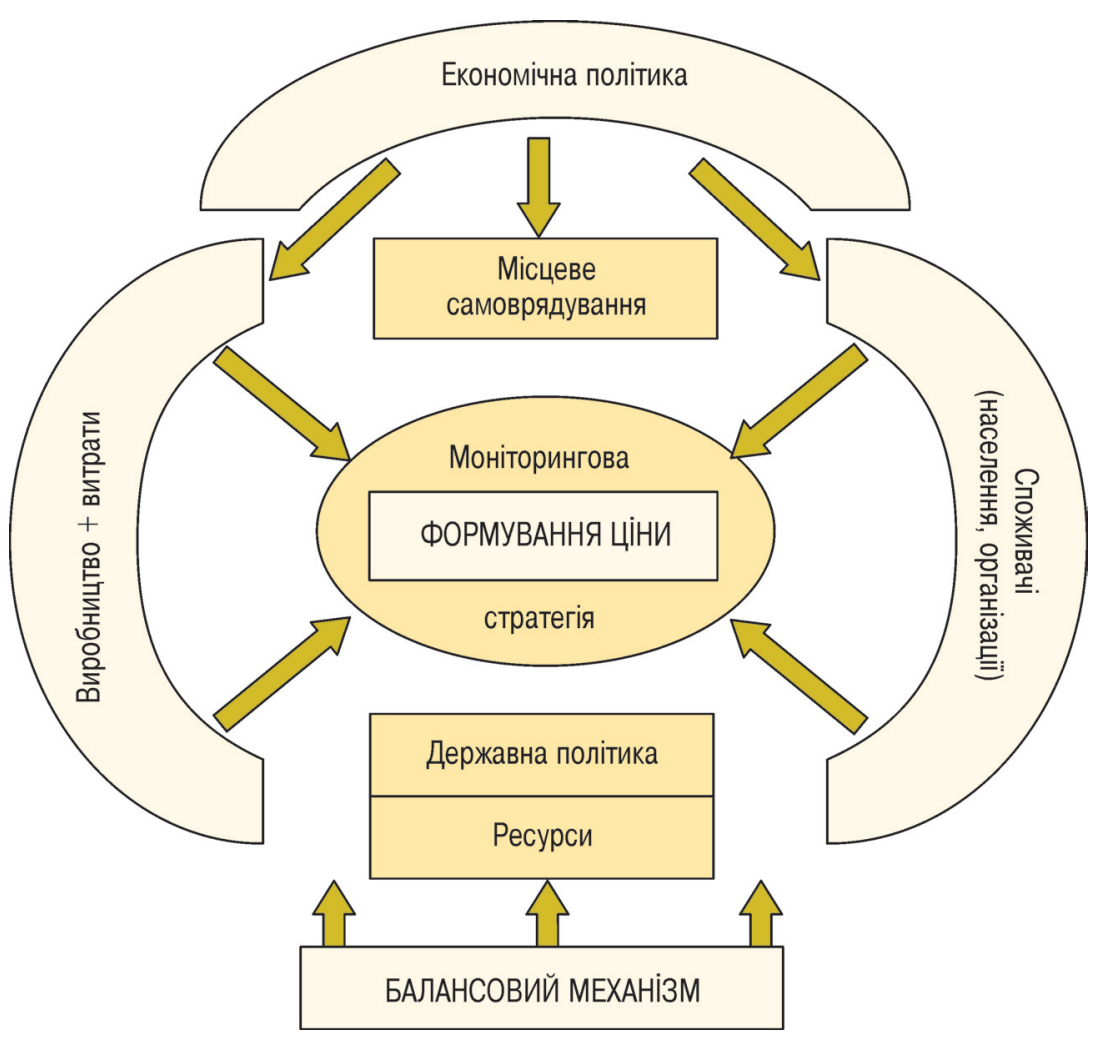

Рисунок 2 - Балансовий механізм формування економічної політики в системі оздоровчо-рекреаційної рухової активності

таннях ціноутворення: рівноправність сторін; взаємозалежність; балансування інтересів усіх учасників економічних відносин в контурі: організація - споживачі - регуляторні органи - конкуренти (рис. 2).

Найбільш впливовим важелем на шляху впровадження сталого розвитку стала соціальна відповідальність суб'єктів системи оздоровчорекреаційної рухової активності, яка має на меті впорядкування, гармонізацію суспільних відносин і забезпечення їх поступального та стабільного розвитку.

Відповідно до європейської практики, соціальна відповідальність бізнесу поширюється на сім напрямів: дотримання прав людини; дотримання вимог законодавства; ділова та корпоративна етика; захист навколишнього природного середовища; співпраця із стейкхолдерами: співробітниками, споживачами, громадою, іншими суб'єктами господарювання; дотримання міжнародних норм поведінки; прозорість та підзвітність. Соціальна відповідальність багатоаспектна та багаторівнева. Вона виявляєть- рекреаційної рухової активності в Україні перебуває на стадії розвитку, оскільки продовжує орієнтуватися на ближнє коло стейкхолдерів - державу, власників фрітнес-індустрії та персонал. Більш широке коло зацікавлених сторін, таких як місцеві громади тощо, поки що не є системною ознакою.

На наш погляд, потребують уваги вдалі практики співпраці органів місцевого самоврядування та спортивних функціонерів на рівні регіону, на прикладі м. Харкова. Філософія розвитку сфери фрізичної культури і спорту заснована на:

- координації та сприянні діяльності підприємств, закладів, установ та організацій міста, усіх форм власності з питань сім'ї, молоді, гендерної рівності, протидії торгівлі людьми, організації оздоровлення та відпочинку дітей, фрізичної культури та спорту;

- виділенні пріоритетних напрямів діяльності в м. Харків з питань сім'ї, молоді, забезпечення рівних прав та можливостей жінок і чоловіків, протидії торгівлі людьми, організації оздоровлення та відпочинку дітей, фізичної культури та спорту, інвестиційної діяльності та іміджевих проєктів, всебічна підтримка таких напрямів;

- наданні пропозицій до створення та підтримки підприємств, закладів, установ та організацій, діяльність яких спрямована на розвиток зазначених сорер;

- сприянні забезпеченню фрінансування підприємств, закладів, установ та організацій комунальної власності територіальної громади міста, які діють з питань сім'ї, молоді, фрізичної культури та спорту в інтересах територіальної громади м. Харків, та сприяння розвитку здорового способу життя;

- забезпеченні взаємодії підприємств, закладів, установ та організацій із зазначених питань з органами державної влади, профспілками, іншими недержавними та громадськими організаціями, недопущення та врегулювання напружених і конфрліктних ситуацій;

- участі у формуванні та реалізації кадрової політики в інтересах територіальної громади міста з питань сім'ї, молоді, фрізичної культури та спорту; 
- сприянні матеріально-технічно му забезпеченню підприємств, закладів, установ та організацій комунальної власності територіальної громади м. Харків з питань сім'ї, молоді, фрізичної культури та спорту;

- сприянні нормативній та програмній підтримці підприємств, закладів, установ та організацій зазначених ссрер у межах своєї компетенції;

- розробці та впровадженні з урахуванням комплексу маркетингових досліджень масштабних спортивних подій, спрямованих на формування іміджу міста на національному та міжнародному рівнях;

- просуванні масштабних спортивних подій, які проводяться на території м. Харків, у мережі Інтернет, у регіональних, всеукраїнських та зарубіжних засобах масової інформації.

Проте, на наш погляд, окремої уваги потребує з боку органів державної влади та місцевого самоврядування створення регіональних ресурсноінформаційних центрів, які сприятимуть розвитку індустрії фрітнесу та рекреації в регіонах, через об'єднання громадянського суспільства, бізнесу у сфрері фрітнесу та здоров'я і держави для підняття позицій України в рейтингах здоров'я та покриття фрітнеспослугами.

Потребують вирішення проблеми функціонування системи контролю та прогнозування для регулювання конкуренції у фрітнес-індустрії; ранжування фрітнес клубів; посилення публічного адміністрування у фітнес-індустрії; конвергенції регіонів.

На фрормування соціальної відповідальності суб'єктів системи оздоровчо-рекреаційної рухової активності в Україні вливає ряд факторів:

- структура економіки;

- іноземні інвестиції (міжнародна практика);

- неефективна система соціального захисту;

- регуляторний тягар (приховування реальних прибутків; «тіньова» зайнятість);

- відсутність інституційної підтримки (відсутність урядового органу, який міг би запроваджувати інструменти, стандарти й методики реалізації політики соціальної відпові- дальності та розвиненої мережі неурядових організацій, які могли б підтримувати діяльність із соціальної відповідальності);

- трудове законодавство (численні порушення існуючих норм і вимог законодавства; характерний високий рівень безробіття, незахищений ринок праці, низька зайнятість жінок на ринку праці).

Висновки. Організаційно-управлінська та економічна діяльність у системі оздоровчо-рекреаційної рухово активності населення спрямована на задоволення зростаючих потреб населення у фрізкультурно-оздоровчих послугах високої якості, які сприятимуть розвитку людського потенціалу, впровадженню європейської системи цінностей та розвитку сфери фрізичної культури і спорту в регіонах та в країні.

Теоретичний аналіз наукових робіт зарубіжних та вітчизняних учених показав, що механізми державногромадського управління системою оздоровчо-рекреаційної рухової активності забезпечують оптимальне функціонування та сталий розвиток лише у колаборації організаційноуправлінського механізму; нормативно-правового механізму, фрінансовоекономічного механізму та соціального механізму саморозвитку системи в цілому та ї̈ окремих елементів. Соціальна відповідальність суб'єктів системи оздоровчо-рекреаційної рухової активності охоплює освіту різ них верств населення 3 питань здорового способу життя та фрізичної активності; використання масових заходів з метою запобігання конфлліктів та побудови миру; прискорення інтеграції принципів сталого розвитку в контексті масових заходів.

Проте концептуальний апарат управління системою оздоровчо-рекреаційної рухової активності на засадах державно-громадського партнерства тільки формується і ще далекий від завершення.

Перспективи подальших досліджень полягають у науковому обґрунтуванні теоретичних положень та інноваційних технологій реалізації запропонованих складових механізмів державно-громадського у управління соціальною відповідальністю суб'єктів системи оздоровчо-рекреаційної рухової активності, що сприятиме фрормуванню ефективної вітчизняної системи управління сферою ффізичної культури і спорту.

Конфлікт інтересів. Автор заявляє, що відсутній будь-який конфрлікт інтересів.

\section{ЛITEPATУPA}

1. Ажиппо 0, Путятіна Г. Діалектичний підхід до структурно-фуункціонального менеджменту в системі оздоровчо-рекреаційної рухової активності населення. Слобожанський науково-спортивний вісник. 2017; 6 (62): 7-10. DOl:10.15391/snsv.2017-6.001.

2. Андрєєва 0, Дутчак М, Благій 0 . Теоретичні засади оздоровчо-рекреаційної рухової активності різних груп населення. Теорія і методика фрізичного виховання і спорту. 2020; 2: 59-66 DOI: 10.32652/tmfvs.2020.2.

3. Дутчак MB. Теоретико-методологічні засади формування системи спорту для всіх в Україні [авторесрерат]. Київ; 2009. 39.

4. Дутчак М. Парадигма оздоровчої рухової активності: теоретичне обгрунтування і практичне застосування. Теорія і методика фізичного виховання і спорту. 2015; 2: 44-52.

5. Дутчак М. Рухова активність: термінологія та класифікація. Проблеми активізації рекреаційно-оздоровчої діяльності населення. Матеріали X Всеукр. наук.-практ. конф. 3 міжнар. участю. Львів: ЛДУФК; 2016. $351-3$

6. Дутчак М, Баженков Є. Теоретичний аналіз десрініції «оздоровчо-рекреаційна рухова активність». Спортивна наука України. 2015; 5: 56-63. URL: http://nbuv.gov.ua/UJRN/ SNU_2015_5_11

7. Жданова 0, Чеховська Л. Основи управління сферою фрізичної культури і спорту [навчальний посібник]. Львів: ЛДУФК; 2017. 244.

8. Имас ЕВ, Дутчак МВ, Трачук СВ. Стратегии и рекомендации по здоровому образу жизни и двигательной активности Киев: Олимпийская лит.; 2013. 528.

9. Імас $€$, Мічуда Ю. Тенденції розвитку у ссрері фізичної культури та спорту в умовах сучасного ринку. Теорія і методика фізичного виховання і спорту. 2015; 2: 142-149.

10. Круцевич ТЮ, Андрєєва ОВ, Благій ОЛ. Потреба людей різного віку у руховій активності як природний фактор залучення населення до рекреаційно-оздоровчої діяльності. Гуманітарний вісник Переяслав-Хмельницького держ. пед. ун-ту. 2015. 430-439.

11. Національна стратегія 3 оздоровчої рухової активності в Україні на період до 2025 року «Рухова активність-здоровий спосіб життя-здорова нація». Київ; 2016.

12. Постанова Кабінету Міністрів України «Про затвердження Стратегії розвитку фізичної культури і спорту на період до 2028 року» від 4 листопада 2020 р. № 1089. Київ. URL: https://zakon.rada.gov.ua/laws/show/1089-2020\%D0\%BF\#Text (цитовано 17 листопада 2020).

13. Путятіна ГМ. Інституційне забезпечення участі громади у розвитку сфрери фрізичної культури та спорту. Молодіжний науковий вісник Східноєвропейського національного 
університету імені Лесі Українки. Фізичне виховання і спорт. 2015; 19: 27-32.

14. Путятіна ГМ. Нормативно-правовий механізм розвитку системи оздоровчорекреаційної рухової активності населення.. Матеріали XI Міжнар. наук.-практ. конф. «Проблеми активізації рекреаційно-оздоровчої діяльності населення». Львів: ЛДУФК; 2018. $17-21$.

15. Розпорядження Кабінету Міністрів України «Про схвалення Стратегії державної політики 3 питань здорового та активного довголіття населення на період до 2022 року» від 11 січня 2018 р. № 10-р. Київ. URL: https://zakon.rada.gov.ua/laws/ show/10-2018\%D1\%80\#Text (цитовано 10 жовтня 2020).

16. Указ Президента України від 28 вересня 2004 року № 1148/2004 «Про Національну доктрину розвитку фрізичної культури і спорTy». URL: https://zakon.rada.gov.ua/laws/show/ 1148/2004\#Text (цитовано 02 листопада 2020).

17. Указ Президента України «Про Цілі сталого розвитку України на період до 2030 року»: за станом від 30 вересня 2019 року. № 722/2019. URL: https://zakon.rada.gov.ua/laws/ show/722/2019\#Text (цитовано12 вересня 2020).

18. Чеховська ЛЯ. Оздоровчий фітнес у сучасному суспільстві [монографія]. Львів ЛДУФК; 2019. 293.

19. International Charter of Physical Education, Physical Activity and Sport. 2020. URL: https://unesdoc.unesco.org/ark:/48223/ pf0000235409 (цитовано 15 жовтня 2020).

\section{LITERATURE}

1. Azhyppo 0 , Putiatina $H$. Dialectical approach to structural and functional management in the system of health and recreational motor activity of the population. Slobozhanskyi naukovosport. visnyk. 2017; 6 (62): 7-10. DOl:10.15391/ snsv.2017-6.001.

2. Andreieva 0 , Dutchak $M$, Blahiy 0 . Theoretical principles of health and recreational motor activity of different groups of the population. Teoriia i metodyka fizvykhovannia i sportu. 2020; 2: 59-66 DOI: 10.32652/tmfvs.2020.2.

3. Dutchak MV. Theoretico-methodical bases of sports for all system formation in Ukraine [author's abstract]. Kyiv; 2009. 39.

4. Dutchak M. Paradigm of health related motor activity: theoretical substantiation and practical usage. Teoriia i metodyka fizvykhovannia i sportu. 2015; 2: 44-52

5. Dutchak M. Motor activity: terms and classification. Problem of activization of recreational and health-related activity of population. Materialy $X$ Vseukr. nauk.-prakt. konferentsii. Lviv: LSUPC; 2016. 351-3.

6. Dutchak M, Bazhenkov I. Theoretical analysis of «health-related and recreational motor activity» definition. Sportyvna nauka Ukrainy. 2015; 5: 56-63. URL: http://nbuv.gov.ua/UJRN/ SNU_2015_5_11

7. Zhdanova 0, Chekhovska L. Fundamentals of managing physical culture and sport sphere [teaching guide]. Lviv: LSUPCS; 2017. 244.

8. Imas EV, Dutchak MV, Trachuk SV. Strategies and recommendations on healthy life style and motor activity Kiev: Olimpiyskaya literatura; 2013. 528.

9. Imas I, Michuda I. Development trends in physical culture and sport under conditions of modern market. Teoriia i metodyka fizvykhovannia i sportu. 2015; 2: 142-149.

10. Krutsevych TI, Andreieva OV, Blahiy $\mathrm{OL}$. The need of people of different ages in physical activity as a natural factor in involving the population in recreational and health-related activities. Humanitarnyi visnyk PereiaslavKhmelnitskoho derzh. ped. universytetu. 2015. 430-439.

11. National strategy for health-related physical activity in Ukraine for the period up to 2025 «Motor activity-healthy lifestyle-healthy nation». Kyiv; 2016

12. Resolution of the Cabinet of Ministers of Ukraine «On approval of the Strategy for the development of physical culture and sports for the period up to 2028" of November 42020
№ 1089. Kyiv. URL: https://zakon.rada.gov.ua/ laws/show/1089-2020-\%D0\%BF\#Text (cited 17 November 2020).

13. Putiatina $\mathrm{H}$. Institutional provision of citizen participation in physical culture and sport sphere development. Molodizhnyi naukovyi visnyk Skhidnoievropeyskoho universytetu im. Lesi Ukrainky. 2015; 19: 27-32.

14. Putiatina $\mathrm{H}$. Normative-legal mechanism of development of the system of health-improving and recreational motor activity of the population. Materialy XI Mizhnar. naukovo-praktychno konferentsii. Lviv: LSUPC; 2018. 17-21.

15. Order of the Cabinet of Ministers of Ukraine «On approval of the Strategy of state policy on healthy and active longevity for the period up to 2022» dated January 11, 2018 No. 10-r. Kyiv. URL: https://zakon.rada.gov.ua/laws/ show/10-2018 \%D1\%80\#Text (cited 10 October 2020).

16. Decree of the President of Ukraine of September 28, 2004 № 1148/2004 «0n the National Doctrine of the Development of Physical Culture and Sports». URL: https://zakon.rada. gov.ua/laws/show/ 1148/2004\#Text (cited 02 November 2020)

17. Decree of the President of Ukraine «0n the Sustainable Development Goals of Ukraine until 2030»: as of September 30, 2019. No 722/2019. URL: https://zakon.rada.gov.ua/laws/ show/722/2019\#Text (cited12 September 2020).

18. Chekhovska LI. Health-related fitness in modern society [monograph]. Lviv: LSUPC; 2019. 293.

19. International Charter of Physical Education, Physical Activity and Sport. 2020. URL: https://unesdoc.unesco.org/ark:/48223/ pf0000235409 (цитовано 15 жовтня 2020).

Надійшла 20.09.2020

\section{ІНФОРМАЦІЯ ПРО АВТОРА}

Путятіна Галина Миколаївна https:orcid.org/0000-0002-9932-8326, e-mail: putiatina.g@khdafk. com

Харківська державна академія фізичної культури

вул. Клочківська 99, м. Харків, 61058, Україна.

\section{INFORMATION ABOUT THE AUTHOR}

Putiatina Galina https:orcid.org/0000-0002-9932-8326, e-mail: putiatina.g@khdafk.com.

Kharkiv State Academy of Physical Culture

Klochkivska str. 99, Kharkiv, 61058, Ukraine 